\title{
Research On The Evaluation For Employees' Safety Quality Of Electric Power Enterprises Based On AHP
}

\author{
Yi-Ming Zhao \\ Department of Electrical Engineering, North China Electric Power University, Baoding, China
}

2948439919@qq.com

Keywords: Safety quality; Analytic hierarchy process; Evaluation index; Weight; Consistency check

\begin{abstract}
By studying the concepts of safety quality and the safety condition of electric power enterprise, an evaluation index system for employees' safety quality of electric power enterprises is established, which includes 4 first-level indexes, 11 second-level indexes, and 47 third-level indexes. Then, the hierarchy model for this evaluation is constructed by using analytic hierarchy process, and the factors' weights in the system are ranked. Results show that safety ability is the chief factor of employee's safety quality, then is safety knowledge and last are physiological quality and psychological quality. This conclusion basically reflects the practical situation and provides a basis for controlling and reducing the man-related accidents.
\end{abstract}

\section{Introduction}

In recent years, China's electricity production remained overall stable situation, but production safety situation is still grim. The accidents of electricity safety production occurred sometimes. Through the investigation and analysis, it can be found that the accidents occurred were associated with a lower quality of their safety-related, such as the lack of safety knowledge, security capabilities and so on [1].

As the most active factor in power production activities is the person, who is also the most difficult to control, safety production depends on the quality of their safety level. The high-quality workforce make a facilitating role in safety production [2]. Therefore, taking a in-depth study, decomposing the indicators and quantifying evaluation for the employees' safety quality of electric power enterprises is not only an effective method of improving the quality of workforce safety, which is related to one of the core issues of safety quality of electric power enterprises, but also an urgent task faced by safety researchers $[3,4]$. From the concepts of employees' safety quality, combine literature with actual power companies, determine the evaluation index system and apply the analytic hierarchy process to establish the evaluation model, which can reflect the characteristics and level of China's power quality of their safety.

\section{The Establishment Of Safety Quality Evaluation Index System}

The Structure Of Evaluation System. As an organic system, the evaluation index system of employees' safety quality of electric enterprises can be divided into the following four levels [5]:

(1) The target layer, namely the quantified results of employees' safety qualities at all levels.

(2) The system level. The safety quality system is divided into four sub-systems which have logical relationship: safety knowledge, safety capabilities, physical safety and psychological safety.

(3) The state level. From the corporate employees constitute departure, it will be divided into three levels: decision-making, management and operational level.

(4) The variable layer. The measurable, comparable indicators are used, which are the most basic elements that make up the index system.

The Construction Of Index System. According to the target level, the system level, the state level and the variable index layer architecture, combine with the characteristics of power enterprises, analyze and summarize all kinds of factors related to safety quality, based on the principles and indicator attributes, the evaluation system of employees' safety quality is divided into four 
dimensions and three layers.

The four dimensions contains safety knowledge, safety capabilities, physical safety and psychological safety.

The three layers contains decision-making, management and operational level.

The entire evaluation system contains first level indicators, second level indicators and third level indicators, which is shown in Table 1.

Table 1. The evaluation index system of employees' safety quality in power enterprises

\begin{tabular}{|c|c|c|}
\hline First level indicator & Second level indicator & Third level indicator \\
\hline \multirow{15}{*}{$\begin{array}{l}\text { Safety knowledge } \\
\text { A1 }\end{array}$} & \multirow{4}{*}{ Decision-making } & $\begin{array}{c}\text { Safety knowledge test } \\
\end{array}$ \\
\hline & & $\begin{array}{c}\text { National laws, regulations, policies, knowledge of } \\
\text { safety }\end{array}$ \\
\hline & & $\begin{array}{l}\text { Industry safety standards and norms related } \\
\text { knowledge }\end{array}$ \\
\hline & & Administration production safety knowledge \\
\hline & \multirow{5}{*}{ Management } & Safety knowledge test \\
\hline & & $\begin{array}{c}\text { National laws, regulations, policies, knowledge of } \\
\text { safety }\end{array}$ \\
\hline & & Administration production safety knowledge \\
\hline & & Department production safety norms and duties \\
\hline & & Safety sector management methods and measures \\
\hline & \multirow{6}{*}{ Operational level } & Safety knowledge test \\
\hline & & Safety regulations mastery \\
\hline & & Mastery of production safety rules \\
\hline & & Emergency and escape knowledge \\
\hline & & Professional emergency plan content mastery \\
\hline & & Mastery of job positions and risk control measures \\
\hline \multirow{11}{*}{$\begin{array}{l}\text { Safety capabilities } \\
\text { A2 }\end{array}$} & \multirow{3}{*}{ Decision-making } & Availability perform guard duties \\
\hline & & $\begin{array}{l}\text { Leadership and decision-making ability of risk } \\
\text { prevention }\end{array}$ \\
\hline & & The ability to deal with emergencies \\
\hline & \multirow[b]{2}{*}{ Management } & Availability perform guard duties \\
\hline & & $\begin{array}{c}\text { The department level security management } \\
\text { capabilities }\end{array}$ \\
\hline & \multirow{6}{*}{ Operational level } & Job safety skills \\
\hline & & Availability perform guard duties \\
\hline & & Use labor protection articles situation \\
\hline & & Site emergencies and ability to handle emergencies \\
\hline & & Electric shock first aid means to acquire status \\
\hline & & $\begin{array}{l}\text { Find a job site accidents and the ability to } \\
\text { eliminate }\end{array}$ \\
\hline \multirow{6}{*}{ Physical safety A3 } & \multirow{3}{*}{$\begin{array}{c}\text { The basic quality of } \\
\text { staff }\end{array}$} & Online job seniority \\
\hline & & Natural age \\
\hline & & Education qualifications \\
\hline & \multirow{3}{*}{ Employee health } & $\begin{array}{c}\text { Whether it has the physical condition of the job } \\
\text { requirements }\end{array}$ \\
\hline & & The number of sick days per year \\
\hline & & Medical eligibility \\
\hline \multirow{4}{*}{$\begin{array}{l}\text { psychological safety } \\
\text { A4 }\end{array}$} & \multirow{2}{*}{$\begin{array}{l}\text { Mental health } \\
\text { disorders }\end{array}$} & Whether there is a serious mental disorders \\
\hline & & Meets the requirements of the job Mental Health \\
\hline & \multirow{2}{*}{$\begin{array}{c}\text { Social safety } \\
\text { psychological quality }\end{array}$} & Mental health \\
\hline & & Interest in the work \\
\hline
\end{tabular}




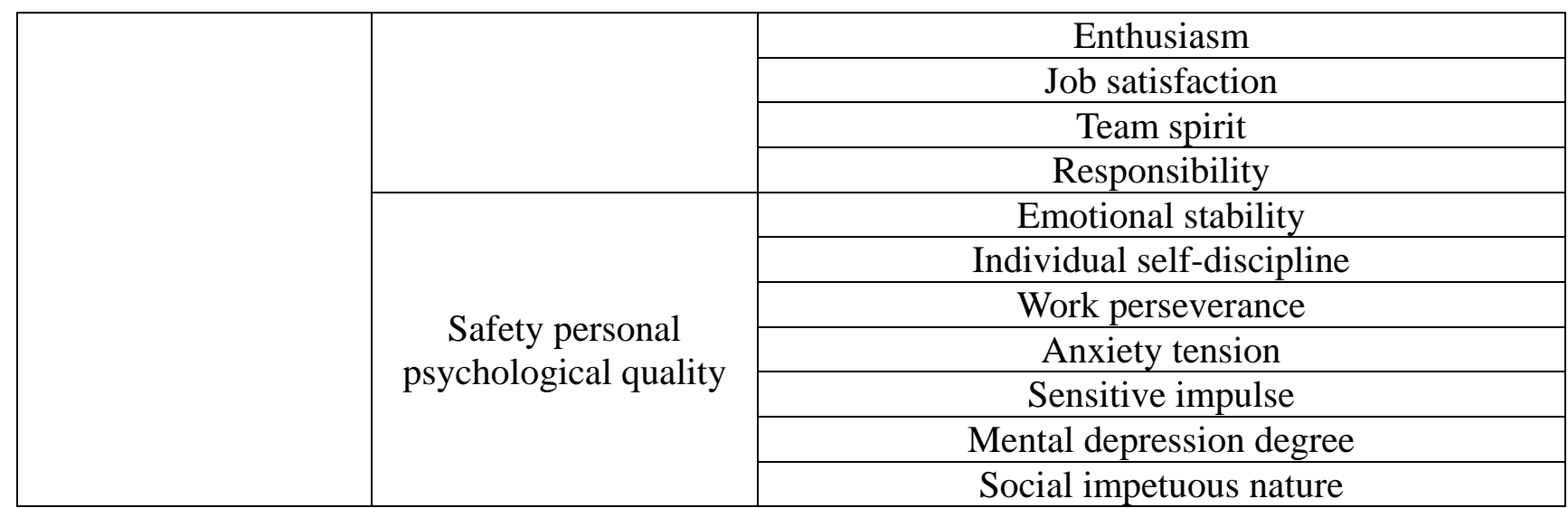

\section{The Determination Of Index Weight}

Construct The Judgment Matrix. Through expert scoring, determine which factor is more important than another and the importance degree, which should give a certain value for it. The first level indicators of the proposed evaluation system have four, which is shown in Table 2. The matrix is constructed by experts scoring. Use the numbers one to nine and its reciprocal to represent the importance scale. Where 1 represents two equally important elements; 3, 5, 7, 9 represents the slightly importance, clearly importance, highly importance and absolutely importance; 2, 4, 6, 8 represents the median of two adjacent odd-standard.

Table 2. The judgment matrix of first level indicators

\begin{tabular}{|c|c|c|c|c|}
\hline$A$ & $A_{1}$ & $A_{2}$ & $A_{3}$ & $A_{4}$ \\
\hline$A_{1}$ & 1 & $1 / 3$ & 3 & 5 \\
\hline$A_{2}$ & 3 & 1 & 5 & 7 \\
\hline$A_{3}$ & $1 / 3$ & $1 / 5$ & 1 & 3 \\
\hline$A_{4}$ & $1 / 5$ & $1 / 7$ & $1 / 3$ & 1 \\
\hline
\end{tabular}

Calculate The Weight. Use the square root method of AHP method to calculate the largest eigenvalue judgment matrix and corresponding feature vectors, which are shown as follows:

(1) Calculate the n-th root of each row's product of the judgment matrix $W_{i}=\sqrt[n]{\prod_{i=1}^{n} a_{i j}}$, thus, $W_{i}=\sqrt[4]{\prod_{i=1}^{4} a_{i j}}=\left(\begin{array}{llll}1.4953 & 3.2011 & 0.6687 & 0.3124\end{array}\right)^{T}$.

(2) Normalized the vector $W=\left[\begin{array}{llll}W_{1} & W_{2} & \mathrm{~L} & W_{n}\end{array}\right], W_{i}=W_{i} / \sum_{i=1}^{n} W_{i}$, thus, $W=\left[\begin{array}{llll}W_{1} & W_{2} & \mathrm{~L} & W_{n}\end{array}\right]^{T}=\left(\begin{array}{llll}0.2634 & 0.5638 & 0.1179 & 0.0550\end{array}\right)^{T}$.

Which is proposed feature vector, namely the weight vector of evaluation indicator.

(3) Calculate the maximum characteristic value of the judgment matrix $\lambda_{\max }=\frac{1}{n} \sum_{i=1}^{n} \frac{(A W)_{i}}{W_{i}}$, thus, $\lambda_{\max }=\frac{1}{4} \sum_{i=1}^{4} \frac{(A W)_{i}}{W_{i}}=4.1169$.

Judgment Matrix Consistency Test.(1) Calculate the consistency index C.I

C.I $=\left(\lambda_{\max }-n\right) / n-1$

Where $n$ is the order number of the judgment matrix. Thus,

C.I $=\left(\lambda_{\max }-4\right) / 3=0.039$

(2) Find mean random consistency index according to Table 3. $\quad$ R.I $=0.89$. 
Table 3. The value of mean random consistency index

\begin{tabular}{|c|c|c|c|c|c|c|}
\hline $\mathrm{n}$ & 1 & 2 & 3 & 4 & 5 & 6 \\
\hline $\mathrm{R} . \mathrm{I}$ & 0.00 & 0.00 & 0.52 & 0.89 & 1.12 & 1.25 \\
\hline $\mathrm{n}$ & 7 & 8 & 9 & 10 & 11 & 12 \\
\hline R.I & 1.35 & 1.42 & 1.46 & 1.49 & 1.52 & 1.54 \\
\hline
\end{tabular}

(3) Calculate the consistency ratio C.R .

$C . R=C . I / R . I=0.039 / 0.89=0.0438$

When $C . R<0.1$, the judgment matrix has a satisfactory level of consistency, test passed. Similarly, secondary indicators can be calculated for each index corresponding to a weight value, as shown in Table 4.

Calculate Mixed Weight. When the weight of each indicator corresponding to the last layer is obtained, multiply layer by layer (ie, second level indicators for level indicators corresponding weight value is multiplied by the weight value of an index to obtain two indicators right target layer weight value) and the target layer mixed index weights can be obtained. The results of mixed weight is shown in Table 4.

Calculate The Weight Of The Third Level Indicators. Because the third level indicators of the employees' safety quality evaluation system is in larger quantities, and it is difficult to determine the index relative to the corresponding second level indicators of the degree of importance. Therefore, this paper simplified it by taking the two indicators corresponding to the weight of the average of three indicators obtained weights.

Table 4. The weight of first and second level indicator

\begin{tabular}{|c|c|c|c|c|}
\hline $\begin{array}{c}\text { First level } \\
\text { indicator }\end{array}$ & Weight & $\begin{array}{c}\text { Second level } \\
\text { indicator }\end{array}$ & Weight & Mixed weight \\
\hline \multirow{3}{*}{$A_{1}$} & \multirow{3}{*}{0.2634} & A11 & 0.517 & 0.136 \\
\hline & & A12 & 0.359 & 0.095 \\
\hline & & A13 & 0.124 & 0.033 \\
\hline \multirow{3}{*}{$A_{2}$} & \multirow{3}{*}{0.5638} & A21 & 0.074 & 0.042 \\
\hline & & A22 & 0.257 & 0.145 \\
\hline & & A23 & 0.669 & 0.377 \\
\hline \multirow{2}{*}{$A_{3}$} & \multirow{2}{*}{0.1179} & A31 & 0.167 & 0.020 \\
\hline & & A32 & 0.833 & 0.098 \\
\hline \multirow{3}{*}{$A_{4}$} & \multirow{3}{*}{0.0550} & A41 & 0.540 & 0.030 \\
\hline & & A42 & 0.163 & 0.009 \\
\hline & & A43 & 0.297 & 0.016 \\
\hline
\end{tabular}

\section{Conclusions}

Combining with the actual fact of power enterprises and related research, this paper established the employees' safety quality evaluation index system in power enterprises, which includes four first level indicators, eleven second level indicators and forty-seven third level indicator. The AHP method is applied to construct the hierarchy model, which provides a practical method for evaluating the employees' safety quality. By solving the AHP model, the relative importance of power quality of their safety evaluation index of sorted, namely safety capabilities (0.5638) is the first, safety knowledge (0.2634), followed by physiological safety (0.1179) again, safety psychological (0.0550) for the bottom. It is targeted to make the point to enhance the power of employees safety education, which provides a basis for reducing electricity production accidents caused by human factors.

\section{References}

[1] Zhang Hong, Liu Dunyi. Evaluation Index Systems of Electric Enterprise Safety Management 
Capability. Journal of WUT (Information and management engineering), Volume 30, Issue 4 (2008), P. 662-664.

[2] Li Cunbin, Liu Haoran, Li Peng. Optimal Allocation Method for Power Grid Enterprise Staff Ability and Quality. East China Electric Power, Volume 41, Issue 6 (2013), P. 1341-1344.

[3] Wang Wei, Chen Xiaoqiang. Human resources optimal allocation method based on fuzzy mathematics. China Management Informationization, Volume 11, Issue 6 (2008), P. 93-95.

[4] Tian Jianding, Guo Hexin. Assumption of establishing the capability management system of intellectual staff and workers in power enterprises. Shanxi Electric Power, Volume 35, Issue 2 (2007), P. 69-71.

[5] Wang Fuxin, Ren Juan. Human resources optimization allocation model based on human matching for position. Technology and Innovation Management, Volume 32, Issue 3 (2011), P. 237-241. 